\title{
TRTaKadeMi
}

ISSN 2149-9446 | Cilt 06 | Sayı 13 | Eylül 2021 | Yapay Zekâ

\section{Cahit Arf'in “Makine Düşünebilir mi ve Nasıl Düşünebilir?” Adlı Makalesi Üzerine Bir Çalışma}

\author{
Filiz SARI*
}

\begin{abstract}
Öz
Bu çalışmada, Cahit Arf'in 1959 yılında yazdığı "Makine düşünebilir mi ve nasıl düşünebilir?” makalesinde makine ve düşünme fenomenlerini birlikte ele alışı felsefi bir perspektifle çözümlenip bu sorunun cevabına ilişkin anlatımlar ilgili literatürden faydalanılarak soruşturulmaktadır. Makinelerin düşünme yetisine sahip olup olamayacağı sorusu, tarihsel süreçte örtük olarak dillendirilmiş olsa da açıkça ilk defa Alan M. Turing tarafindan 1950 yılında ele alınmıştır. 1958 yılında halka açık bir konferansta soruyu gündeme getiren Arf, bir insanın düşündüğünün göstergesi sayılabilecek kimi özelliklere makinelerin sahip olma imkânı üzerine tespitlerde bulunmasının yanı sıra düşünebildiğine ikna olabileceğimiz makine tasarım örnekleri ile karşımıza çıkmaktadır. Ona göre makineler; dil kullanabilme, hesap yapabilme, benzerlik kurabilme ve elimine edebilmeye dayalı düşünme tarzları ile mantısal ve analitik işlemleri yapar şekilde zihinsel yetilerle tasarlanabilir ve insan beyninin işleyiş tarzıyla makinelerin işleyiş tarzı arasında benzerlikler bulunur. Fakat Arf, insan ve makine arasındaki temel farkı, insanın sahip olduğu estetik bilincin makinelere kazandırılmasının güçlüğünde görmektedir. Bu bağlamda çalışmada, Arf'in makalesinde öne sürdüğü argümanlar ile insan ve makine arasındaki benzerlik ve farklılıklar belirtilmeye çalışılmış ve Arf'in düşünen makine tasarımları ele alınmıştır.
\end{abstract}

Anahtar Kelimeler: Cahit Arf, Makine, Düşünme, İnsan, Düşünen Makineler

*100/2000 YÖK Doktora Bursiyeri, Muğla Sıtkı Koçman Üniversitesi, Sosyal Bilimler Enstitüsü, Felsefe ABD. filiz-sari@hotmail.com.tr

Sarı, F. (2021). Cahit Arf'in “Makine Düşünebilir mi ve Nasıl Düşünebilir?” Adlı Makalesi Üzerine Bir Çalışma . TRT Akademi , 6 (13) , 812-833 . DOI: 10.37679/trta.962940

\section{Derleme Makale}

Geliş Tarihi: 05.07.2021

Kabul Tarihi: 23.09.2021

ORCID ID: 0000-0003-4275-193X DOI: 10.37679/trta.962940 


\title{
TRTakademi
}

ISSN 2149-9446 | Volume 06 | Issue 13 | September 2021 | Artificial Intelligence

\section{A Study on the Article of Cahit Arf "Can a Machine Think and How Can it Think?"}

\author{
Filiz SARI
}

\begin{abstract}
In the current study, how Cahit Arf handled the phenomena of machine and thinking in his article "Can a machine think and how can it think?" written in 1959 was analyzed from a philosophical perspective and the explanations about the solution of this problem were questioned in light of the relevant literature. The question of whether machines can think or not, although it has been implicitly investigated in the historical process, was first explicitly addressed by Alan M. Turing in 1950. Raising the question at a public conference in 1958, Arf came up with machine design examples that we could be convinced that they could think, as well as making explanations about the possibility of machines having certain features that could be considered as indicators of ability of a person' $s$ thinking. However, Arf sees the main difference between human and machine in the difficulty of imparting the aesthetic consciousness of humans to machines. In this context, in the current study, Arf's arguments put forward in his article and similarities and differences between human and machine were tried to be explained and Arf's thinking machine designs were discussed.
\end{abstract}

Keywords: Cahit Arf, Machine, Thinking, Human, Thinking Machines

Review Paper

Recieved: 05.07.2021

Accepted: 23.09.2021 


\section{Giriş}

Herhangi bir işi yapmak veya etki oluşturmak üzere tasarlan nesnelere, insani yetiler kazandırma düşüncesi, Daidalos'un Antik Yunan'daki insan heykellerine kadar götürülebilir. Menon diyaloğunda Sokrates; Daidalos'un yaptı̆̆ heykelleri, göz kapakları açık olarak tasarladığına ve yürümelerini sağlamak için ayaklarını birbirinden ayırdığına fakat onlar kaçmasınlar diye de zincire bağladığından söz etmiştir (Platon, 2011, s.184). Antik Yunan'dan beri insan ürünü nesnelere, insani yetiler kazandırma arzusu canlılığını korumaktadır. İnsani yetiler fiziksel ve zihinsel olarak ayrıldığında asıl arzu, fiziksel olanlardan ziyade zihinsel olanları kazandırmaya yöneliktir çünkü 18. ve 19. yüzyılı etkisi altına alan Endüstri Devrimi, insanların fiziksel yetileri sayesinde yapabildiği işleri onların yerine yapan ve onlar gibi aktivitelerde bulunan nesnelerin yani makinelerin yapılabildiğini göstermiş; bu aşamadan sonra makinelerin zihinsel yetilere de sahip olabileceği düşüncesi önem kazanan bir soru olarak belirginleşmiştir.

1950'lerden beri ön plana çıkmaya başlayan düşünen makinelerin yapılabilirliğine ilişkin soru örtük de olsa ilk olarak Rene Descartes'ın Metot Üzerine Konuşma (1637) adlı eserinde görülmektedir. Ruh ve bedenden oluşan insan tasavvurunda düşünme yetisini, maddesel dünyanın ötesinde, ruhsal töz olarak ortaya koyan Descartes; makine ve insan arasındaki farkı belirtmeye yönelik ifadeleriyle aslında "Makineler düşünebilir mi?" sorusunu sormuş ve felsefi perspektifinden makine ve insan arasındaki ayrılığı iki hususla vurgulamıştır. illki, makinelerin, insanların düşüncelerini başkalarına bildirirken yaptığı gibi söz ve işaretleri bir araya getirmesinin mümkün olamayacağıdır. Dolayısıyla dil kullanan bir makine tasavvur edilse bile insanlar gibi anlamlı cevaplar vermeyi ve sözleri düzene sokmayı başaramaz. İkincisiyse makineler, pek çok şeyi insanlar gibi hatta insanlardan daha iyi yapsalar da bazı şeyleri mutlaka yapamayacaklardır; bunun nedeni onların, insanın sahip olduğu ve hayatın her durumunda hareket etmesine imkân veren ruhsal töze sahip olmamalarıdır (1984, 52-53).

Gottfried Wilhelm Leibniz de Monadoloji (1714) adlı eserinde "düşünmek, hissetmek ve algılar edinmek üzerine yapılandırılmış" $(2011,102)$ bir makinenin üretilebileceğini öne sürmüştür. Fakat bu tür bir makinenin imkânı, zihni de bir makine olarak tasarlamakla mümkün olacaktır. Makine olarak tasavvur ettiği zihni bir değirmene benzeten Leibniz, onun içine girdiğimizde birbirini iten parçalar göreceğimizi ama algılayan makinenin algılarını, hislerini, düşüncelerini ve tüm bunları açıklayacak bir şey göremeyeceğimizi söyler $(2011,102)$. Leibniz, zihnin makine olarak tasavvur edilmesine karşıdır ancak zihinsel yetileri olan ve genel ifadeyle düşünen makinelerin de olabileceğine inanmaktadır (Reyhani, 2020, s.17). 
Leibiniz'den yaklaşık yüz sene sonra Charles Babbage, 1830'larda dijital bilgisayarların öncüsü sayılan analitik bir makine tasarımıyla karşımıza çıkmıştır. Bu tasarım, delikli kartlar vasıtasıyla işleyerek istenilen aritmetik işlemleri yapmaya programlanabilecektir. Henüz tasarım hâlindeki makinenin işleyiş düzeni ve bir dizi hesaplamaların nasıl yürütülebileceği hakkında bir program yazan Ada Lovelace da makinenin kendiliğinden bir şey yaratma iddiasında olamayacağını, sadece ondan yapmasını istediğimiz görevleri yerine getireceğini ve gerçekliği tasarlama yeteneğine sahip olamayacağını iddia etmiştir (Ifrah, 2000, s.168).

Bu örnekler, örtük olarak da olsa, düşünme yetisine sahip makinelerin mümkün olup olamayacağı sorusunu merkeze alan ve cevap bulmaya çalışan arayışın ilk göstergeleri olmuştur. Fakat bu sorunun yoğun olarak tartışıldığı asıl dönem, yukarıda belirttiğimiz gibi 1950’lere dayanmaktadır.

Alan M. Turing'in, "Hesaplama Makineleri ve Zekâ" adlı makalesine, "Makineler düşünebilir mi? sorusunu dikkate almayı öneriyorum." (1950, 433) cümlesiyle başlaması bir tesadüf değildir ve ilk kez makinelerin düşünebileceklerine ya da bir zihne sahip olup olamayacaklarına dair soruyu bu denli açıkça ileri sürmektedir. Turing, bu makalede, düşünebilen bir makinenin mümkün olduğunu kabul etmemizi sağlayacak bir düşünce deneyi sunmuştur. "Turing testi" olarak da adlandıran deney, yazışma yoluyla, üç kişi arasında gerçekleşmektedir; bir sorgulayıcı ve iki sorgulanan. Sorgulananlardan biri kadın diğeriyse erkektir fakat erkek, kadın taklidi yaparak sorgulayıcıyı kadın olduğuna inandırmak ister. Onlarla yazışmaları sonucunda sorgulayıcı, cinsiyetleri tahmin eder ve bu taklit oyunu defalarca tekrarlanır. Turing, sorgulanan ve kadın taklidi yapan erkeğin yerine aynı görevi üstlenen bir bilgisayar koyduğumuzda sorgulayanın cinsiyetleri belirleme başarısında bir değişme olmaz ve sorgulayıcı bilgisayarla yazıştığının farkına varamazsa testin geçildiği ve o makinenin düşünebildiğine ikna olmaktan başka seçeneğimiz olmadığını belirtmiştir (1950, 433-435).

Turing'in ciddiyetle sorduğu ve cevap vermeye çalıştı̆̆ “Makineler düşünebilir mi?” sorusunu; J. McCarthy, M. L. Minsky, N. Rochester ve C. H Shannon 1956'da Dartmouth Kolejinde bir konferansta cevaplandırmaya çalışmışlardır. Konferansın içeriği, bir makinenin öğrenme ve zekâ vasfina sahip olabileceği kabulüne dayanarak makinenin nasıl problem çözeceği, ne tür bir dil kullanacağı, soyutlama yapabilme ve kavram üretebilme yetilerinin sınırları üzerine tartışmalar olarak belirlenmiştir (McCarthy v.d., 1955). Yapılan konuşmalarda McCarthy, "Yapay zekâ" ifadesini tarihte ilk kez kullanmıştır ve "ilk aşamalarında, yapay zekâ alanının temel amacı, insanların temel problem çözme becerilerine sahip bilgisayar programlarının icat edilmesi" (Nilsson, 1995, s. 9) olarak tanımlanmıştır. 
Turing'in sorusu ve Dartmouth konferansıyla başlayan süreçle birlikte, düşünen makinelerin mümkün olabileceğine dair inanç, kimi zaman güçlenmiştir kimi zaman zayıflamıştır ve terk edilmiştir (Moor, 2006); fakat böyle bir inancı güçlendirmek ya da terk etmek öncelikle "Makineler düşünebilir mi?" sorusunu sormaktan geçmektedir. Yukarıda da değinmiş olduğumuz gibi, Türkiye'de bu önemli sorunun, ilk kez 1959 yılında Ord. Prof. Dr. Cahit Arf (Bkz. Not 1) tarafindan halka açık bir konferansta dile getirilmiş olması, Türkiye'de yapay zekâ üzerine yapılan felsefi tartışmaları anlamlandırmamız açısından, Arf'in düşüncelerinin incelenmesini ve değerlendirilmesini son derece önemli kılmaktadır.

Bu çalışmanın amacına doğrudan katkıda bulunacak tarihsel arka plana az da olsa değinerek sorunun düşünce dünyasındaki önemi vurgulanmış olup, çalışmamızdaki soruşturmamızın merkezi olan Arf'in "Makine düşünebilir mi ve nasıl düşünebilir?" sorusuna vermeye çalıştığı cevapları belirginleştireceğiz. Böylece bu soruyu, Arf'in döneminin bilimine paralel ve daha ötesinde ürettiği fikirlerini takip ederek insan ve makine arasındaki benzerlik ve farklılıklar üzerinden ele almaya çalışacağız.

\section{Arf'in Düşünen Makine Tasarımları ve Onların Düşünebildiklerine Dair Fikirleri}

Atatürk Üniversitesinin 1958-1959 öğretim yılı açılışı vesilesiyle üniversite çalışmalarını muhite yayma ve halk eğitim konferansları başlığı altında, yapılan konferansın davetlisi olan Arf; konuşmasının büyük bir bölümünü (Bkz. Not 2) düşünen makineleri betimlediği anlatımlara ayırmıştır. Fakat önce şu tespitte bulunur:

İkinci Dünya Harbi'nden sonra gazeteler, radyolarda müspet ilimlerin yarattğı üç mucizeden bahsedildi ve edilmektedir. Bunlar atom enerjisinin elde edilmesi, duruma göre karar veren ve bu kararlara uygun işler yaptıran düşünen makineler, diğer tabiriyle elektronik beyinler ve nihayet fezaya firlatilan aletler, yani sun'i peyklerdir $(1959,94)$.

Arf, düşüncenin somut göstergesini farklı etkilere verilen farklı tepkiler olarak ortaya koymuştur (Bkz. Not 3) ve insanın kendisine söylenen farklı sözlere veya maruz kaldığı farklı etkilere farklı sözlerle tepki verdiğini ve bu verilen tepkilerin de onun düşündüğünün kanıtı olarak alınması gerektiğini vurgulamıştır $(1959,94)$. Böylece Arf, etki ve tepki ilişkisine değinerek düşünce ve davranış arasında bir bağ kurar ve bu bağı da dil fenomenine bağlı olarak ele alır. Onun düşüncesinin arka planında, 1950'lerin popüler, davranışçılık ekollerinin bulunduğu söylenebilir. Felsefi davranışçılık olarak adlandırılan görüşe göre, "herhangi bir zihinsel terimin anlamı, onun dışarıdan gözlenebilen davranışlara ve durumlara ilişkin terimlerle bağlantısına göre belirlenir" (Gödelek, 2013, s.108). Bir felsefi davranışçı olan Gilbert Ryle, Zihin Kavramı’ adlı yapıtında, düşünme gibi zihinsel faa- 
liyetleri gözlemlenebilen insan davranışları üzerinden tanımlarken temel olarak bilinemez şeyler üzerinde söz söyleme hakkı tanıdığından, davranışçılık ekolünün çekiciliğinden bahsetmektedir $(2011,37)$. Davranışçı ekol denilince akla gelen bir diğer isim ruh bilimci Burrhus Frederic Skinner ise insanı kabaca etki ve tepki yaşantısı içinde çevresel koşulların bir ürünü olarak görmektedir, dil fenomeni de bu yaşam içinde ortaya çıkan sözel davranış terimine gönderme yaparak (1957, 2), etkiye karşılık verilen tepkide açığa çıkmaktadır.

Anlaşılabileceği üzere Arf makalesinde, davranış̧̧ılık düşüncesini benimser görünmektedir ve bu anlayışa göre düşüncenin göstergesi sayılan etki, tepki ve sözel davranış üçlüsüne bağlı davranış örüntüsüne sahip iki makine örneği vermiştir. Onun ilk örneği olan çalar saat, bahsi geçen örüntüyle tanımlandığında şöyle işlemektedir: Çalar saate, saat dörtte bizi uyandırmasını söylediğimizde, tabii bunu ona kendi dilinde söyleriz, cevabını kendi dili ile verir ve saat dörtte çalmaya başlayarak seslenir. Biz de ona uyandığımızın cevabını yine onun dilinde düğmesine basarak veririz. Yalnız başka bir düşünme alternatifi de vardır: Bizi uyandırmasını bekçiden de isteyebiliriz ve saat dörtte kapımıza vurduğunda uyanmadığımızı gözlemlerse başımıza bir bardak su dökerek bizi uyandırması mümkündür. Fakat çalar saatin başka bir yönteme başvurup bizi uyandırması, ona uygun bir düzenek ilave etmediğimiz takdirde mümkün gözükmemektedir $(1959,95)$.

İkinci olarak verilebilecek diğer bir düşünen makine örneği de telefondur. Ahizesini kaldırdığımızda ona konuşmak istediğimizi söyleriz. Kendi dilinde "düüt" diye cevap veriyor olması konuşma isteğimizi karşılayabileceği anlamına gelmektedir. Bu durumda kiminle konuşmak istiyorsak onun adını, makinenin anlayacağı şekilde numaraları tuşlayarak söyleriz ya "gırr" diye bir ses kişinin çağrıldığını söylemekte ya da "düüt düt düt" diyerek onun işinin olduğunu ve bize cevap veremeyeceğini söylemektedir $(1959,95)$.

Arf, bu örneklerinde makinenin etkiye karşı tepki, yani girdiye karşı çıkt, vermesini gözler önüne sererken aynı zamanda makinenin kullandığı dile de vurgu yapmaktadır. Çalar saati istediğimiz zaman diliminde bize haber vermesi için kurarak yani küçük ibresini istediğimiz saate denk getirerek telefonu da istediğimiz kişiyi araması için tuşlarını çevirerek kendi dillerinde onlara taleplerimizin bilgisini ulaştrrırız. Arf'in bu örnekleri makine ve insan iletişimini, iki tarafinda anlayabileceği bir dile dayandırmaktadır. Çağın getirdiği noktada karmaşık yapılı makinelerin yazdığımız ve konuştuğumuz dil unsurlarını çözümleyerek bilgiye dönüştürmesi ve bu sayede makineler ile kendi dilimizde konuşabilme imkânı "doğal dil işleme (NLP)" programları sayesinde mümkün olmuştur (Yılmaz, 2020, s. 9). Doğal dil kullanımı, insanın düşünebildiğinin en temel işaretlerinden biridir (Churchland, 
2018, s. 172) ve bu işareti bir makineye uyarlamak amacıyla Joseph Weizenbaum 1966 'da "ELIZA" adlı bir bilgisayar programı yazmıştır (Solso v.d., 2010, s. 614). ELIZA, biriyle sohbet ederken gerçekten anlıyormuş gibi görünmesine rağmen onun kurduğu cümleler sadece karşısındaki kişiden duyduklarının bir nevi tekrarına dayalı cümlelerdir (Churchland, 2018, s. 173). Bu nedenle ELIZA, istenilen başarıyı tam olarak karşılayamamıştır; fakat doğal dili insanlar gibi kullanan makine tasarımlarına ilham kaynağı olmuştur.

Arf çalar saat ve telefon örneklerinin, düşünen makinelerin var olduğuna dair bizlerde henüz tatmin edici bir inanç oluşturmadığının farkındadır; bu yüzden hesap ve miras meselelerini çözebilen iki makine taslağı ileri sürerek tezini güçlendirmek istemiştir. Bu örneklerden ilki şöyledir: Bir kümeste tavuk ve tavşanların bulunduğunu düşünelim; kümeste 510 baş ve 1420 ayak sayılır, acaba hayvanlardan kaçı tavşan kaçı tavuktur? Bu soru basit adımlarla ve dört işlemle rahatlıkla çözülebilmekte ve sonucunda kümeste 200 tavşan ve 310 tane tavuk olduğu sonucuna varılmaktadır. Aynı işi yapan bir makine de aşağıda gösterilen şekildeki gibi huniler ve bilyeler yardımıyla tasarlanabilir $(1959,95)$.

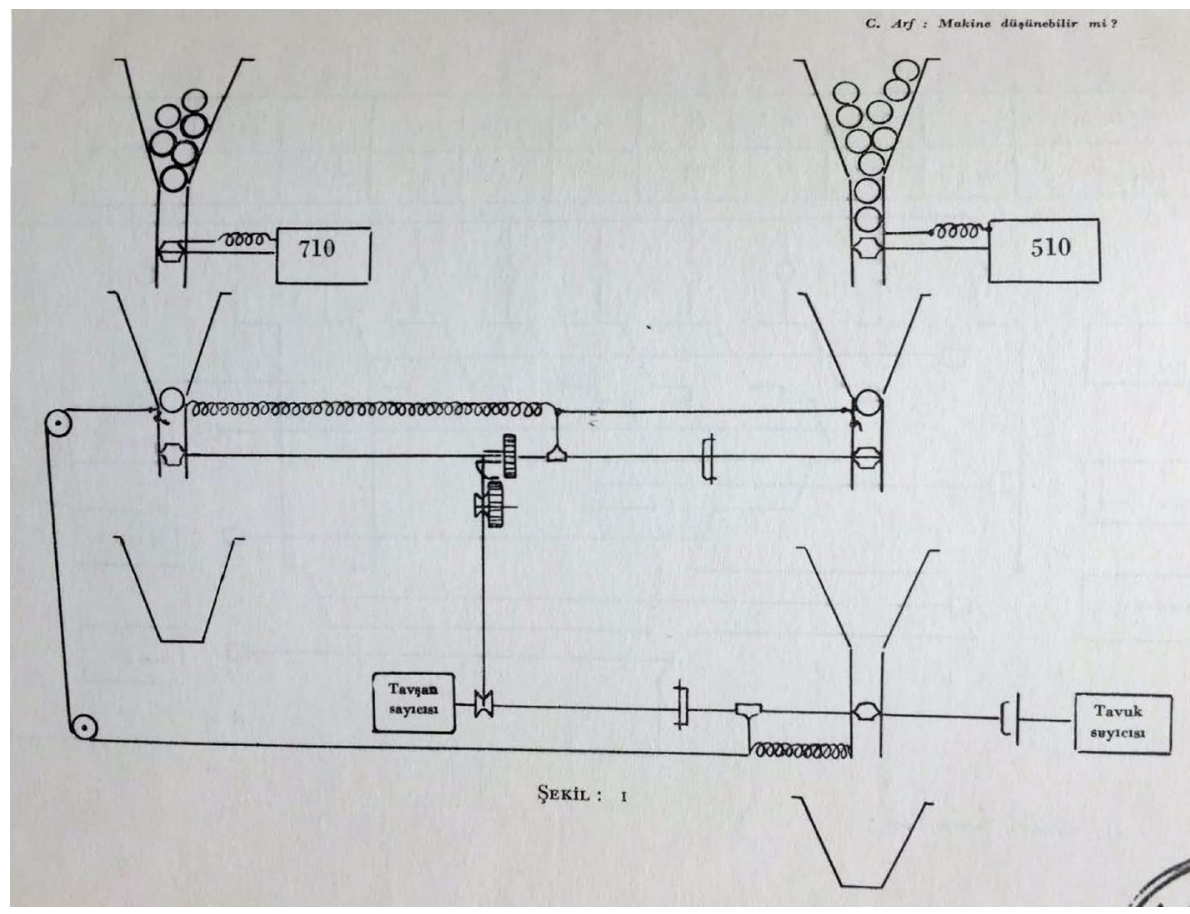

Şekil 1. Kümesteki Tavşan ve Tavuk Sayısını Hesaplayan Makine Tasarımı (Arf, 1959)

Yukarıdaki şekilde, iki ayrı huni ve onların içinde de bilyeler görünmektedir. Hunilerin ağızlarına turnikeler yerleştirip onları taksimetreye bağladığımızda, sayaç- 
larda birer sayıda mandal düşürerek turnikeleri kitleyecektir. Böyle bir düzenek sayesinde makine ona verilen buyruklara göre işlemeye başlayacak baş ve ayak sayılarını tavuk ve tavşanlara göre dağıtacaktır $(1959,96)$.

Daha sonra Arf, ikinci örneği olan, miras meselesini çözen makinenin nasıl çalıştğını bize göstermiştir ve bir makine tasarımı daha sunmuştur.

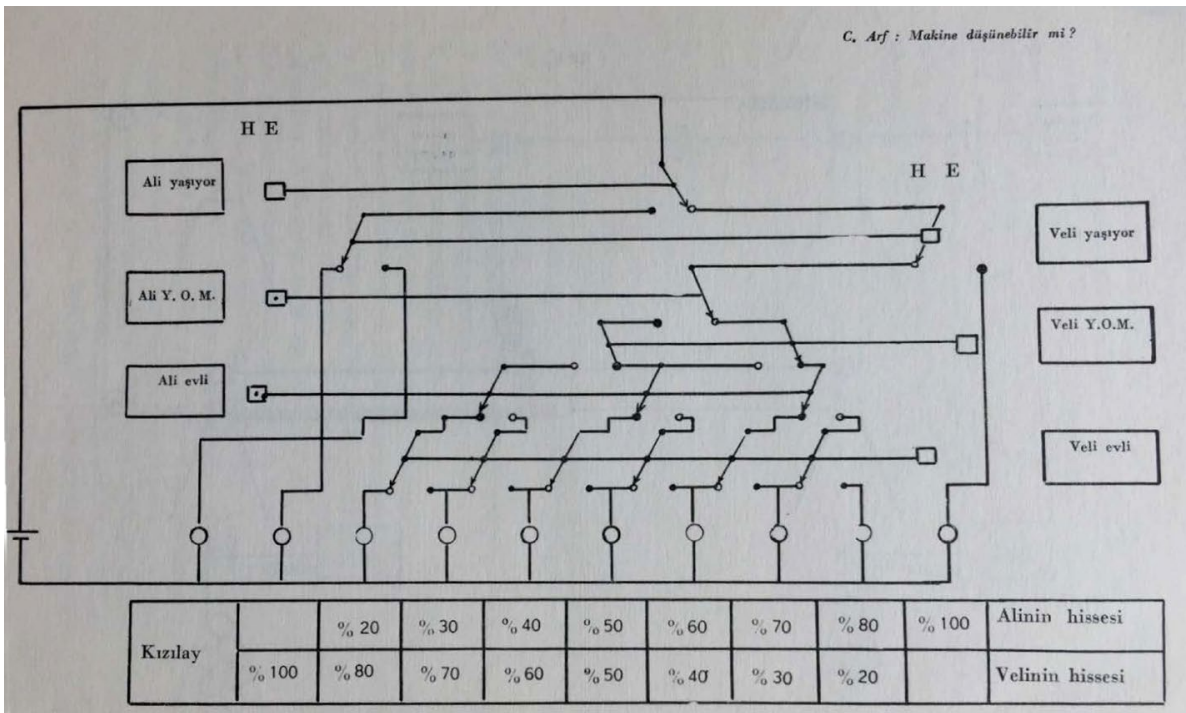

Şekil 2. Miras Meselesini Çözen Makine Tasarımı (Arf, 1959)

Ahmet, mirasının Ali ve Veli adlı iki oğlu arasında şu şekilde paylaşılmasını istemiştir: Oğullarından biri yaşıyor diğeri ölmüşse mirasın tamamı yaşayana verilecek, oğulları ölmüşse mirası Kızılay’a bağışlanacak; iki oğlu da yaşıyorsa, evlilik durumları ve yüksek eğitimleri aynıysa mirası ikiye bölünecektir. Bunun yanı sıra oğulları yaşıyor fakat evlilik ve yüksek eğitimleri bakımından durumları faklıysa; yüksek eğitimli olanın payı yüzde 20 artacak ve diğerinki yüzde 20 eksilecek ve evli olanın payı yüzde 10 artacak, diğerininki yüzde 10 eksilerek miras pay edilecektir. Böylesi şartları karmaşık gibi görülen miras dağılımını yapacak makine, birkaç ampul ve pil yardımıyla üretilebilir ve yukarıdaki tasarımdaki karelerin $\mathrm{E}=$ evet veya $\mathrm{H}=$ hayır hizasına gelmesiyle birlikte makine sorulan soruları on tane lambasından birini yakmakla cevaplandırabilir $(1959,98)$.

Arf, bu tür bir makineyi "bir Amerikan oyuncağı" $(1959,98)$ atfıla "ENIAC"a, 1946 yılında üretilen belli bir diferansiyel işlemini çözebilen 30 ton ağırlığında ve bir oda büyüklüğündeki (Yılmaz, 2020, s. 15) bilgisayara benzetmiş ve bir dipnotla bunu bildirmiştir. Elektronik numaralı integratör ve hesaplayıcı anlamına gelen bu makine, 
17.468 vakum tüpüne sahipliğiyle 174 kilovat enerji harcamaktadır; fakat zamanla bu makine yerini daha güçlü ve kompleks olmasına karşın küçük ve kullanışlı bilgisayarlara bırakmıştır (Solso v.d., 2010, s. 589-590).

Bu dipnota değindikten sonra, bahsi geçen makine tasarımları üzerinden Arf'in çözümlemelerini ele almaya devam ettiğimizde, onların beynimizin temel iki işleyişi hakkında birer örnek olduğunu görebiliriz. Şöyle ki alınan bilgi ile bunlardan çıkarılmak istenen sonuç arasında bağların benzerlerini imgelememizde kurarak bizler de bir şey hakkında sonuca varırız. Böyle bir benzerliğin maddi gerçekliğini temsil eden makinelere "analog makineler" adı verilmektedir ve onların düşünme tarzları "benzerlikle düşünme"ye dayanmaktadır. İkinci düşünme tarzındaysa, ulaşılması gereken bütün sonuçlar değerlendirilmekte ve önceden verilen bilgilere uymayanlar elenerek sonunda karara varılmaktadır. Bu tür makinelere "dijital" denir ki onların düşünüş tarzları eleme (elimination) yöntemine göre işlemektedir (1959, 98-99).

Arf'in analog makine tasvirinde temel faktör, benzerliğe dayalı düşünme tarzıdır; bu düşünme tarzı, zihinsel imgelem gücüne yani insan beyninin o anda orada olmayan nesne ve olayların benzerlerini (Solso v.d., 2010, s. 350) betimleme gücü sayesinde sonuç üretebilmesini sağlar ve makinenin de bunu yaptığı varsayılmaktadır. Aslında Arf, bütün temel mantksal ve aritmetik işlemleri yapabilen "analitik makineler"den (Churchland, 2018, s. 149) bahsetmemesine rağmen onun makineleri sınıflandırışında dijital diye bahsettiği makinelere çok daha yakın olduğu söylenebilir çünkü dijital makineler, aritmetik ve mantıksal işlemleri yapmakta ve elemeye dayalı düşünüş tarzlarıyla sonuca ulaşmaktadır. Bu tür bir makine Turing makinesinin bir örneği olarak biçimsel sembolleri işler. Bu semboller 0 ve 1'dir ve dört işlemden faydalanarak ortaya çıkabilecek her sonuç belirlendikten sonra yazılan programa göre verilen bilgilere uymayanlar elenerek sonuca ulaşılmaktadır (Searle, 2020, s. 20).

Arf, vermiş olduğu makine tasarımlarının her ikisinin de sadece bizim verdiğimiz birer problemi çözebilmelerinin yanı sıra istediğimiz anda tekrar çözebileceğine de değinmiştir. Hatta birinci makine problemi beynimizden daha yavaş çözmesine rağmen ikinci makine sonuca bizden daha hızlı varmaktadır. Fakat bir makinenin cevap vereceği problemlerin sayısını birden on bine arttırırsak ve makine üretilirken ona çözümünü verdiğimiz az sayıda belli problemleri çözüp artırılmış sayıdaki problemleri çözemiyorsa onu yapay bir beyin olarak düşünemeyiz. Bunun nedeni insan beyninin hiç karşılaşmadığı problemleri çözebiliyor olduğuna dair inancımızdır $(1959,99)$.

Bir makinenin işleyişini "yapay beyin”lere benzetme düşüncesinin gerisinde insan beyni gibi etkileri tepkilere dönüştürdüğü varsayımı yatar; makinelerde bu tür bir dönüştürme işi insan tarafindan üretilen bir nesnenin onun tarafindan programlan- 
ması ile gerçekleşir ve "yazılım" paketi denilen talimatlardan oluşan bilgi paketi, makinenin harici veya edilgen bellek bantları gibi çevresel aygıtları olan "donanım"ına yerleştirilerek (Churchland, 2018, s. 151) sanal bir makine meydana getirilir. Daniel Dennett'a göre sanal makine, donanıma bir program yoluyla sokulan ve birçok yapıdan oluşan geçici bir düzenliliktir. Bir yönerge olarak düşünüldüğünde yazılım, yüz binlerce bilgiden meydana gelir ve donanımla tepkimeye girer. İnsan beyninin de böylesi bir işleve sahip olduğunun farkına varılması üzerine makineyi yapay bir beyin olarak tasarlama isteği baş göstermektedir (Zeman, 2006, s. 397-398). Fakat yüz binlerce bilgiyi içeren yazılım, donanımla tepkimeye girmesine rağmen yapay beyin tıpkı insan beyni gibi daha önce hiç karşılaşmadığı problemleri çözebilir mi? İnsanların sinir sistemlerinin, belirli girdi çıkt ilişkilerine göre işlevsel bir düzenlemeye sahip olarak kurulmuş olmayan yani önceden belirli olmayan zihinsel durumları üretmek için nedensel bir kapasiteye sahip olmalarından (Searle, 2016, s. 328) dolayı makinelerin çözemeyeceği problemleri çözebileceğine dair inanç güçlüdür. Arf, tüm bu yaklaşımların izinde insan beyninin karakteristik özelliğini yeni durumlara uyum sağlayabilme yeteneğine sahip oluşunda görerek, böyle bir yeteneğe sahip bir makinenin yapılıp yapılamayacağı sorusunu tekrar sormuş ve kabataslak da olsa insan beyninin işleyişini anlatmıştı $(1959,99)$.

Arf'e göre, öncelikle bir soru belirlenir ve bu belirleme dış etkiler denebilecek söz ve gözlemlerin kayda alınması ile gerçekleşir. Kaydedilen soru, gerçekte böyle bir yerin olup olmadığı bilinmemesine rağmen beynin belli bir bölgesine alınır. Bu bölge, ön hafiza adıyla anılır ve tasnif yeri veya başka bir adla kontrol merkezini harekete geçirerek merkez hafiza denilen bilgi deposundan etkilerle ilgili bilgilerin kopyalarını ön hafizaya yollar. Ön hafizaya hafizadan yollanan bu bilgiler arasında şu tür bilgiler de olabilir: Bir adama sormalı veya bir kitaba bakmalı. Böylece başka insanlar veya kitaplar hafizamızın birer yardımcısı olarak beynimizin dıştan bir parçası olurlar ve bu dıştan parçaya yardımcı hafıza denir. Bilgilerden ön hafizada toplananlar, mantıki hesap ya da benzerlik yöntemini uygulayarak yeni bilgiler çıkaran bir aletin kontrol merkezi tarafindan seçilen yerlere giderler ve orada bir tür dönüşüm (transformasyon) yaşarlar; bunun sonucunda sorunun beyin tarafindan verilen cevabı ortaya çıkmaktadır. Fakat cevap yine kontrol merkezinden geçerek, bir taraftan bir dağıtım organımız yoluyla dışa aktarılırken bir taraftan da hafizamıza kaydedilmektedir (1959, 99-100). Arf, bu söylediklerini şöyle bir şemayla gösterir: 


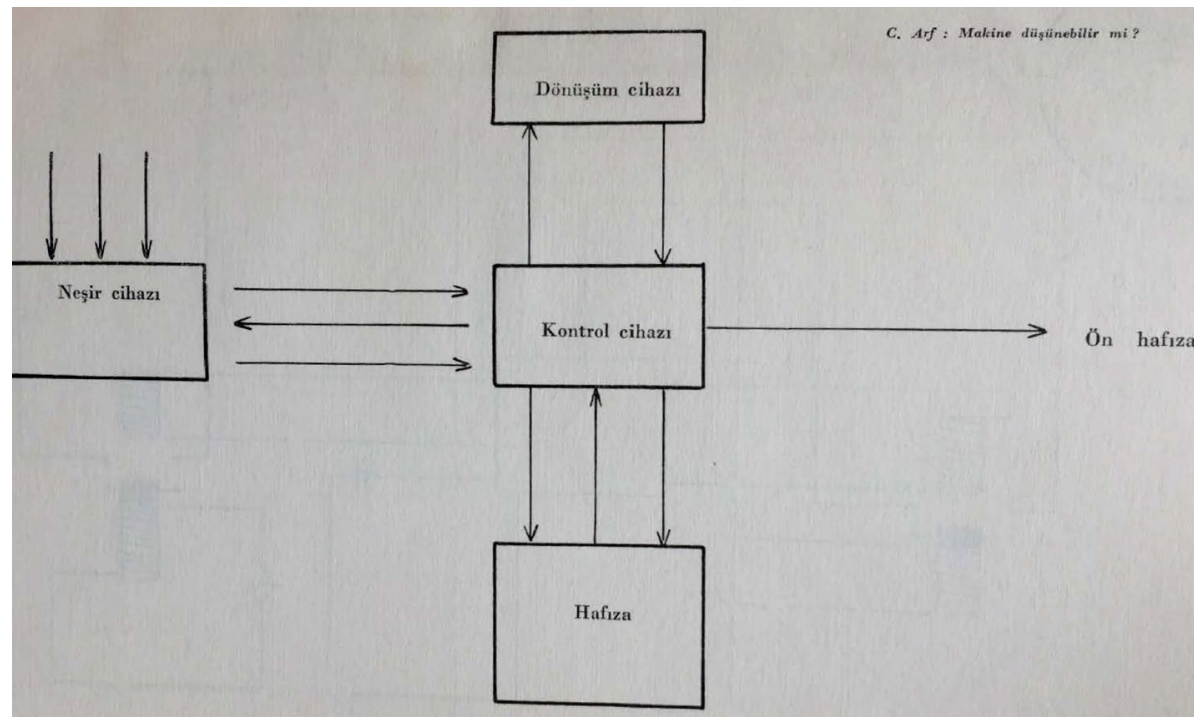

Şekil 3. Insan Beyninin İşleyiş Tarzı (Arf, 1959)

Allen Newell ve Herbert A. Simon'un 1972 yılında insan ve makinenin problem çözme modelinin benzerliklerini ortaya koyduğu modelde, Arf'in ön hafiza ve merkez hafiza belirlenimleri kısa ve uzun süreli bellek olarak karşımıza çıkar. Kısa süreli bellek uzun süreli bellekten sınırlı kapasiteye ve daha az erişim süresine sahiptir. Problem çözme esnasında kısa süreli bellek, sembolleri belirli bir an için tutar. Tüm süreçler girdilerini kısa süreli bellekten alır. Fakat problemin sağlıklı çözülebilmesi için bir problem alanına ihtiyaç vardır; çözüm sırasında bu alan genişletilir veya değiştirilir. Problem çözümünde işlemci sadece geçici çözümü aramakla kalmaz mevcut bilgileri kullanarak çözümün formüle edilmesini sağlar. Çözüm aradığı sırada işlemci, yedekleme yaparak eski bilgi durumlarına geri döner ve çeşitli dönüşümler yaşar. Bu tür adımlar sonunda problem çözülmüş olur fakat insan düşüncesinin dinamikliği göz önüne alındığında teori ile onu tanımlamaya kalkışmak yine de zordur (1972, 4-6).

Arf, dışarıdan edinilen girdilerin makinenin "alış dili"ni temsil ettiğini belirtmektedir; bu girdilerin dönüştürülmüş ve "neşir dili" dediği dağıtım cihazındaki görünümlerine de makinenin dağıtım dili demektedir. Bu şemayı kendimize uyarladığımızda bizim beynimizin alış dili kelimelerden, kelimeler de harflerden oluşur. 0 hâlde beynimizin alıp dönüştürebileceği etkiler, 29 harfin aralıklarla dizilişinden meydana gelir. Örneğin, "Sokağa çıkacağım fakat hava bulutludur." cümlesi böyle bir etkidir. Beyin bu etkiyi hafizasındaki bilgiyle birleştirip şuna dönüştürür: "Şemsiye almalıyım." Görülüyor ki beynimizin her daim yeni problem çözebilmesinin 
nedeni 29 harfin çok büyük sayıda sıralandırılışlarını etki olarak kabul etmesi, anlaması ve bunları hafizasındaki diğer bilgiler, etkiler yardımıyla mantık kurallarına göre dönüştürebilmesi yani başka şekillere çevirebilmesidir. Aynı zamanda Arf'e göre dilimizin zenginliği harflerin sayısıyla alakalı değildir, yalnız iki harf kullanıyor olsaydık da yine de aynı ölçüde zengin bir dilimiz olurdu. Örneğin harf yerine 0 ve 1 işaretlerini kullandığımızı varsayalım. Her kelimeyi 0 ve 1 işaretleriyle yazdığımızda 0 ve 1 işaretlerinin bütün sıralanışlarını girdi olarak kabul eden ve bu girdileri mantık kurallarına benzeyen kurallara göre dönüştüren bir makine dili oluşturabiliriz ve bizim alfabemizin harflerine göre makinede kullanılacak harflerin 0 ve 1'ler ile temsili aşağıdaki tabloda görüldüğü gibidir $(1959,100-101)$.

Tablo 1. Alfabemizdeki Harflerin 0 ve 1 İşaretleri İle Temsili $(1959,101)$

$$
\begin{aligned}
& A=00000, \quad B=00001, \quad C=00010, \quad D=00011, \quad E=001000, \quad F=00101 \text {, } \\
& \mathrm{G}=00100, \quad \mathrm{H}=00111, \quad \mathrm{I}=01000, \quad \mathrm{~J}=01001, \quad \mathrm{~K}=01010, \quad \mathrm{~L}=01011, \\
& M=01100, \quad N=01101, \quad O=01110, \quad P=01111, \quad R=10000, \quad S=10001 \text {, } \\
& T=10010, \quad U=10011, \quad V=10100, \quad Y=10101, \quad Z=10110, \quad O ̈=10111 \text {, } \\
& \text { Ü=11000, I=11001, } \quad \text { Ğ=11010, } \quad \text { Ç=11011, } \quad \text { Ş=11011 }
\end{aligned}
$$

Arf, burada makinelerin 0 ve 1 algoritması ile çalışth̆ından bahsetmektedir. Makinelerin kullandığı biçimsel sistemin içerdiği bütün formüllerin kurulması 0 ve 1 mantığına dayanır. Her formül 0 ve 1 'lerden oluşan sonlu birer dizi olarak makinenin kodunu ya da dilini oluşturur. Makinenin esas ögelerinden olan merkezi işlem biriminde kurulan mantık geçitleri çok sayıda genel ögeyi temsil eder. Bu geçitler girdi olarak 1 ve 0 değerini alır ve bir tane 1 veya 0 değerini çıkt olarak bildirir (Churchland, 2018, s. 152). Bu, makinenin “donanım"ını meydana getirir. Makinenin yerine getirmesini istediğimiz talimatlara göre düzenlenmiş bir program, en temel düzeyde merkezi işletim birimine onun dilinde 0 ve 1 dizileri olarak kodlanmalıdır. Merkezi işletim biriminin tek biçimsel sistemi ve tek anladığı dil 0 ve 1 'lerden oluşur. Fakat kendi dilimizi makinenin anlayacağı şekilde 0 ve 1 'lerden meydana getirerek sayıları, denklemleri, mantıksal ve aritmetik işlemlerle ilgili talimatları makine için anlamlı hâle getirmemize rağmen 0 ve 1'ler yığını bizim için anlamsız görünmektedir (Churchland, 2018, s. 154).

Arf'e göre makineler, 0 ve 1 işaretlerinin bütün sıralanışlarını birbirinden farklı girdiler olarak düşünmemektedir; makinenin büyüklüğüne göre verilen sıralanıştaki 0 ve 1 işaretlerinin sayısı çok büyük olduğunda bu sıralanışı girdi olarak alamayacak, daha doğrusu eksik olarak alacaktır. Böylesi bir eksikliğin insan beyni için de geçerli olduğu söylenebilir. Örneğin 2000 kelimelik bir cümleyi hiç kimse anlayamaz (1959, 
101). Claude Shannon 1948 'de "Matematiksel iletişim Kuramı” adlı makalesinde, makineye yüklenen girdilerin bilgi içeriğinin 0 ve 1 işaretleriyle tanımlanmış sayı miktarına denk geldiğini ifade etmiştir fakat Shannon, 0 ve 1 mantiğıyla oluşturulan bilgi içeriklerine ilişkin girdilerin az sayıda kullanılmasıyla yine de istenilen bilginin makineye ulaştırılabileceğini ön görmektedir (1948, 5-6). Bu bakımdan Arf, 0 ve 1'lerin sıralanışına dayanan girdilerin sayı miktarlarının azlığına rağmen bilgi sağlayabildiğine örtük olarak değinmiş de olsa Shannon'u destekler görünmektedir.

Arf, elektronik beyin adı altında yapılıp kullanılmakta olan, dilleri de 0 ve 1 işaretlerinin sıralanışından oluşan, makinelerin yapılışındaki çok basit esaslara da değinmektedir. Ona göre elektrik düğmelerinin çok basit iki hâli vardır: Ya bu düğmeler elektrik geçirecek durumdadır ya da tam tersidir. Elektrik geçirecek hâlde olması 1 işareti, geçirmeyecek durumda olması da 0 işareti ile temsil edilmektedir. Makinenin ön hafiza diye adlandırdığımız yerinde mesela 100'den fazla elektrik devresi varsa ve bunlardan 100 tanesi makine üzerindeki 100 düğmeye bağlıysa, bu 100 yüz düğmeyi çevirerek makineye 100 işaretlik bir kelime veya cümle söyleyebiliriz. Makine bunu kaydeder ve anlar. Sonrasında sıra, makinenin bu aldığı işaret etkisiyle hafiza dediğimiz kısımdaki bilgilerden, yani cümlelerden bir kısmını ön hafizaya yollamasına gelmektedir. Bunun gerçekleşebilmesi için öncelikle hafiza denilen kısım hakkında bilgi edinmeye ihtiyaç duyulmaktadır $(1959,101)$.

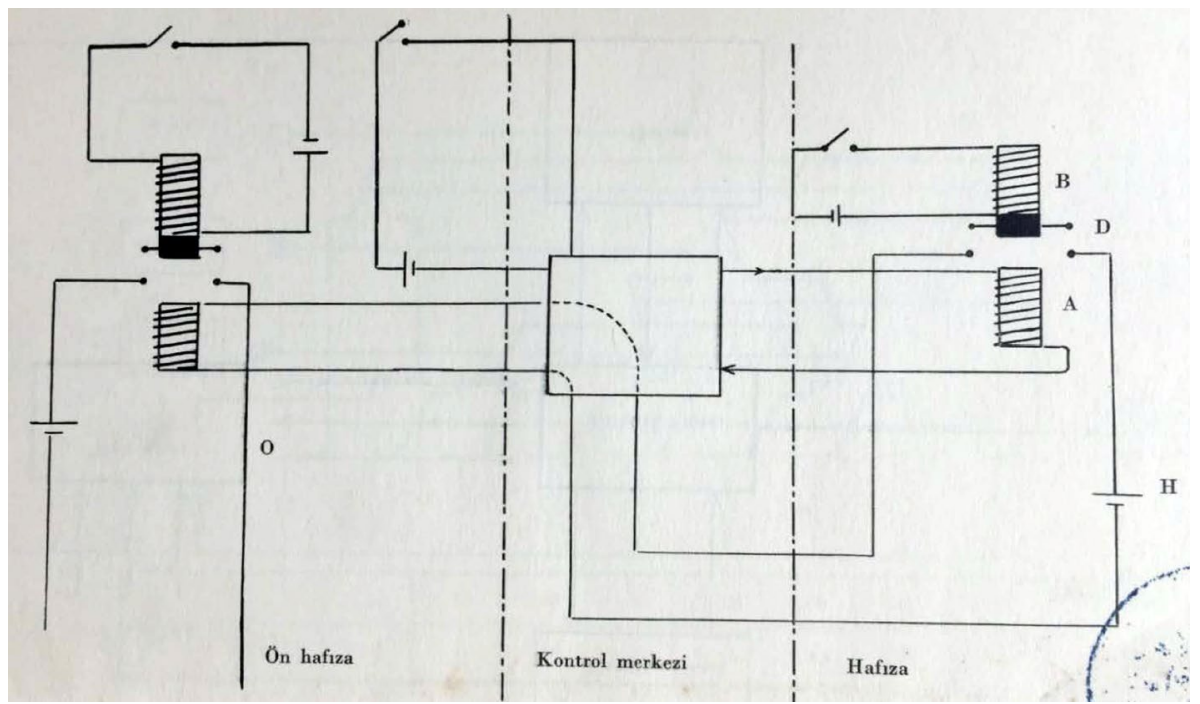

Şekil 4. Elektronik Beyin Adı Altında Anılan Makinelerin Hafiza Kısımları (Arf, 1959)

Arf, yukarıdaki şekilde A ve B harfleriyle temsil edilen yerleri hafiza olarak adlandırır. D harfi ile gösterilen yerse bir demir parçasıdır ve A ile $B$ arasında rahatça dolaşmaktadır. D, B’ye yapışık olduğu zaman H ile gösterilen elektrik devresi O’dadır; 
$D, A^{\prime}$ ya yapışık olduğu zaman $\mathrm{H}$ devresi 1'dedir. $\mathrm{H}$ devresine hafiza ögesi adı verilir. Cihazın hafizasının böyle düzenlenmiş binlerce $\mathrm{H}$ devresinden birleşerek oluştuğu varsayıldığında hafiza binlerce 0 veya 1 işaretinden ibaret bilgiyi saklayacaktır. Bunun yanı sıra yukarıdaki şekilde görüldüğü gibi $\mathrm{H}$ devresinin uçları kontrol cihazına gitmektedir. Birtakım rölelerle, H'deki bilginin ön hafizadaki soruyla ilişki şekline göre, ön hafizadaki yeni bir röleye elektrik verir veya vermez ve böylece hafizada bulunan ve ele alınan soruyla ilgili olan bilgilerin kopyaları ön hafizaya ulaştırılır. Dahası ön hafizada toplanmış olan bütün işaretler dizisinin devreleri, yine kontrol cihazından geçerek mantıki hesap cihazına gider ve orada yine röleler aracılığıyla yeni bir kısım devreleri açar veya kapatırlar. Açılan ve kapanan devreler sorunun mantı kurallarına göre dönüştürülmüş biçimini yani makinenin soruya cevabını ortaya çıkarmaktadır. Dağıtım organı da bu cevabı, daha önce bahsi geçen alfabeye göre bizim dilimize çevirmektedir (1959, 101-102).
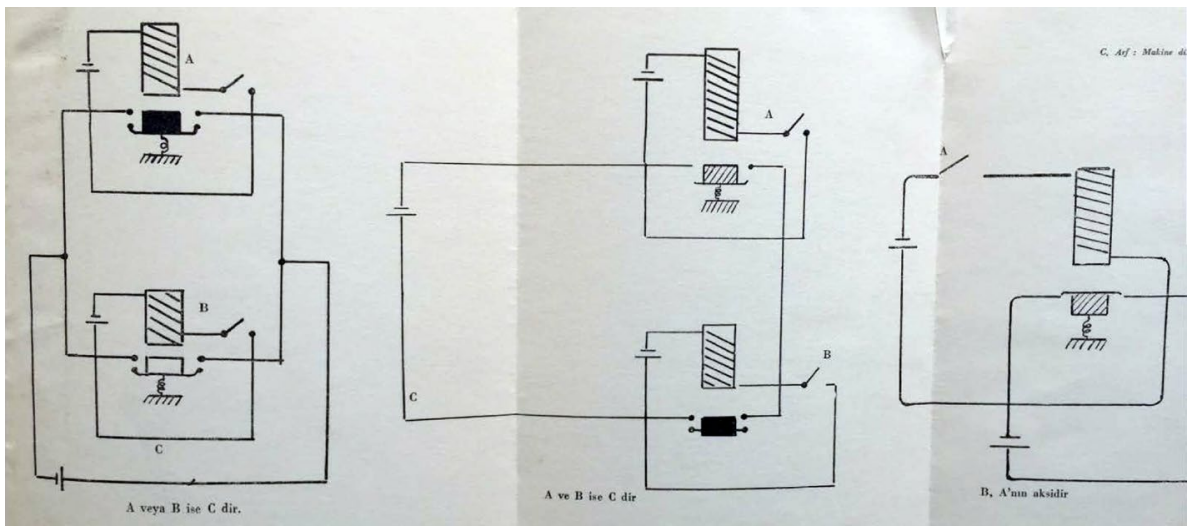

Şekil 5. Üç Mantık Önermesinin Makinedeki Temsili (Arf, 1959)

Makine dili önermeler mantığına uygun şekilde kodlanabilir. Arf'in yukarıdaki şekilde kontrol cihazı olarak gösterdiği alan merkezi işletim birimi adıyla anıldığında onun alt birimleri olan ön hafiza ve hafiza girdi-çıktıları önermeler mantığının formüllerini temsil ederek işlemektedir. Şöyle ki girdi dizesinde temsil edilenler; mantiksal tümel evetleme, tikel evetleme veya koşul ilişkisine göre ya da isteğe bağlı olarak ise-o hâlde yapılı girdiler olarak makineye işlendiğinde çıktı dizileri de ilk ifadenin doğruluğunu temsil edecek şekilde cevabını ortaya koyar (Churchland, 2018, s. 153). Arf, bir makinenin elektrik devrelerinin kapalı oluşunun ifadenin doğruluğunu açık oluşunu da ifadenin yanlışlığını gösterdiğini belirtmektedir ve " $A$ veya $B$ doğru ise $C$ de doğrudur. $A$ ve $B$ doğru ise $C$ de doğrudur. $A, B$ 'nin aksidir, yani $A$ doğru ise B yanlış, $A$ yanlış ise $B$ doğrudur" $(1959,102)$ önermelerinin makinede doğruluğuna ve yanlışlığına göre temsil edilişini şöyle göstermektedir: 
Arf, tüm bu incelemelerinden sonra makineleri insan beyni ile kıyaslayarak makalesini sonlandırmaktadır. Makineler bazı işleri insan beyninden çok çabuk yapabilmelerine rağmen onlarda bulunan en büyük eksiklik kendi kendilerine karar verebilme yetilerinin olmayışıdır çünkü makineler, insana nazaran ilk üretildikleri gibi kalır ve onlara yüklenen programlarının el verdikleri kadar yetkinleşebilirler $(1959,103)$. Arf, burada makinelerin bir problemi çözerken onlara yüklenen programlarının ötesinde, problemin çözümü için, karar veremeyeceğini yani otonom bir varlık gibi davranamayacağını vurgulamaktadır. O hâlde makineler, bir problemin çözümü bakımından, insanla kıyaslandığında sınırlı kapasiteye sahiptirler. Öte yandan sınırlı kapasitelerinden dolayı, onlara yöneltilen sorulara bazen yanlış cevaplar verirken bazen de cevap veremezler. Fakat tüm bu kabuller, bizi, makinelerin insanlardan büyük bir eksikliği olduğu vargısına ulaşttrabilir mi? Turing, Kurt Gödel'in "eksiklik teoremi”ne (1931) atffa bulunarak, yeterli bir güce sahip bir mantıksal sistemin durumlarının, sistemin kendisi tutarsız olmadıkça, sistem içinde kalınarak ne ispatlanabileceği ne de ispatlanamayacağı şeklinde formüle edileceğini belirtir (1950, 442-443). Gödel'in teoremine göre “...doğru matematiksel kanıtlama kurallarının, hiçbir formal dizgesinin (sisteminin) asla (ilkesel olarak bile) basit aritmetiğin bütün doğru önermelerinin saptanmasına yetemeyeceği” tartışmasız kanıtlanır (Penrose, 2016, s. 99). Aynı zamanda bu teorem, uzun sürelerdir, matematikçilerin ve mantıkçıların, sezgisel olduğu düşünülen, karar verilebilirlik kavramının somut bir yönteminin ortaya konulmasının mümkün olamayacağını da ortaya koymaktadır; bu nedenle karar verilebilir kümeler yerine hesaplanabilir işlem ve işlevler dikkate alınmalıdır (Raatikainen, 2021). Ne kanıtlanabilen ne de aksi kanıtlanabilen önermelerin sistemin içinde oluşu ve bu tür önermelerin bulunuşunun oldukça doğal karşılanması, makineler söz konusu olduğunda da Turing için doğal karşılanması gereken bir durumdur (1936, 230). Turing açısından makine tarafindan çözülebilir problemler ile çözülemeyecek problemlerin sayısı aynı sayıda olabilmesinin yanı sıra bir sistemdeki mantık önermelerinin doğru ve yanlışlığına karar vermek çözümsüz bir probleme işaret edeceğinden dolayı Gödel'in teoreminin vargılarına benzer (Kurzweil, 2020, s. 655-656). Bu, şu anlama gelir: tıpkı makineler de insanlar gibi bazı problemleri çözemez ya da probleme dair cevapları doğru olabileceği kadar yanlış da olabilir. Fakat bu eksiklik, insanın lehine olan, insanın makineden üstün olduğu inancına sebep olmamalıdır.

Arf, makalesinin sonlarına doğru kendi kendisini yetkinleştirebilen bir makinenin tasarlanabileceğini fakat insan beyni ile makine arasındaki temel farkın, insan beyninin estetik niteliğe sahip etkileri alıp onları işleyebilmesi ve yine estetik nite- 
likte olan kararlar verebilmesi, verilen bir işi yapıp yapmama konusunda kendini özgür hissetmesine karşın makinede bu özelliklerin benzerlerin bulunmayacağını ifade etmektedir $(1959,103)$. Arf, insan beyni ile makine arasındaki temel farkı; etik, dini, bilimsel, tarihsel, ekonomik vb. yargılar üretebilme niteliğine sahip olup, bu niteliklere göre eylemde bulunma özgürlüğü yerine estetik nitelikli etkileri anlama, onlara göre karar verme ve özgürce eyleyebilme yeteneğine sahip olmakta görmektedir. Peki, Arf, özellikle neden insanın estetik bilincini ön plana çıkarmaktadır? Estetik olay, süje ve objenin birbiriyle bağında ortaya çıkan, estetik obje ve ona tüm ruhsal aktlarıyla yönelmiş, estetik algıya sahip ve bu algısından zevk alan bir süjenin varlığını gerektirir. Süje bakımından estetik, estetik olay yaşanırken süjede gerçekleşen değişikliklere odaklanarak onun duygu, hayal ve tasavvurlarının birleşiminde hem kendinde hem de objede yaşanan farktır. Bunun yanı sıra süje, estetik olayın objesiyle kurduğu bağ ile burada kastedilen herhangi bir sanat dalı ve onun eseri olabilir, dünyanın ve kendinin mahiyetini kavramaya eğilimlidir (Tunalı, 1983, s. 7-14). Estetik bilinç, diğer bilinç türlerinden (etik, dini, bilimsel, tarihsel, ekonomik vb.) farklı olarak süjenin mahiyetiyle ilişkilenen duygu, his ve heyecanlarını içinde barındırması ve onlardan beslenmesiyle, mantıksal ve kural tabanlı yargı üretiminin bir adım ötesinde bulunduğundan insan ve makine arasındaki farkı belirginleştirmektedir (Ömerustaoğlu, 2007, s. 18-19). Arf, açısından bu tür olayların temel karakteristiği, hepsinin belirsizlik unsuru içermesi ve bunların şaşmaz biçimde uydukları kuralların mevcut bulunmayışıdır. Belirsizlik karakterine sahip olan insan dışı doğa olayları vardır; bu olaylar atom içinde gerçekleşir $(1959,103)$. Arf, burada ismini açıkça zikretmese de, "kuantum mekaniği teorisi"ne gönderme yapar. Bu teoriye göre evren ve onun içlemi, Nelson Goodman'ın 1950'lerde nesneleri tanımlarken kullandığı ifadesi, "Bir nesne, tekdüze bir süreçtir." inancı ile ilişkilendiğinde, süreçler ve süreçler arasında gerçekleşen olayların tümüdür; süreç içinde gerçekleşen tüm olaylar tanecikli, belirsiz ve ilişkiseldir (Rovellı, 2019, s. 134-135). Makinelerde veri depolama ve transferlerde görev alan en küçük dosya birimi olan "bit"ler, kuantum mekaniği söz konusu olduğunda klasik bitlerin sağladığı 0 ve 1 seçeneğinden daha da fazlasını sağlamasının yanı sıra sonsuz olasılıkta kesişme olanağına imkân veren seçenekleri doğurur. Aynı zamanda her bir atom alt parçacı̆̆ı, uzaktan etki ile diğer parçacıklarla etkileşimde bulunur ve bir parçacıktaki değişim diğer parçacıkları da etkiler (Tarlacı, 2009). Bu bakımdan Arf'a göre bir yere kadar küçük sayıda atom içinde gerçekleşen olaylar makinelerin işleyişinde etkili hâle getirilebilirse makinelerin estetik bakımdan insan beynine benzeyebileceği ümidi doğar ve bir makine herhangi bir müzik parçasını güzel bulmadığını ifade edebilir. Yalnız bu iş, yüzyıllar sonra bile ve belki hiçbir zaman gerçekleşemeyebilir 
$(1959,103)$. Olasılıksal neden oluşları kural kabul ederek belirsizlik ilkesine göre işleyen makinelerin yapılma hayali, günümüzde çokça tartş̧lan "kuantum bilgisayarları”nın inşasını amaçlayan çalışmaların yolunu açmıştır (Heil, 2015, s. 322). Fakat bu bilgisayarlara özgü algoritmaların yazımı, Arf'in öngörüsüne katılarak uzun zamanlar alacağa benzemekte hatta belki de hiçbir zaman yapılamayacaktır.

\section{Sonuç}

Bu makalede Arf'in konuşmasında yanıt vermeye çalıştığı "Makine düşünebilir mi ve nasıl düşünebilir?" sorusunun çok önceden beri, kimi zaman örtük kimi zaman da açıkça sorularak düşünce dünyasını meşgul ettiği tespit edilmiştir. Arf'in bu tür bir soruyu halka açık bir konferansta dillendirmesi ve düşünen makinelere dair ikna edici makine tasarım örnekleri vermesi, fikirlerini çözümlemeye değer kılmasının yanı sıra konuşmasını yaptığı yılı açısından da tarihsel önemine işaret etmektedir çünkü Arf'ten kısa bir süre önce bu sorunun çok benzeri Turing tarafindan sorulmuş ve cevaplandırılmaya çalışılmıştır. Arf, düşündüğüne ikna olabileceğimiz makine örnekleri ve kendi tasarımları ile karşımıza çıkarken öncelikle, bir insanın düşündüğünün göstergesi sayılabilecek, etkilere verilen tepkiler niteliğindeki, davranış örüntülerini göz önünde bulundurmuş ve onların sözel davranışları açığa çıkarttı̆̆nı belirtmiştir. Dolayısıyla Arf'in, zihinsel faaliyetlerin göstergelerini gözlemlenebilir davranış örüntüleri içinde gören davranışçı yaklaşımı benimsediği fark edilecektir. Davranışçı perspektife göre makineler, yüklenen girdilere dilsel geri dönüşler yapmalı, çıktılarını dilsel fenomenler ile ifadelendirmelidir ki bizi düşündüğüne ikna edebilsin. Arf'in üzerinde durduğu bu husus, makinelere kazandırılmak istenen dil yetisine yönelik ilk programlama çalışmalarının yapıldığı (NLP) ve "ELIZA" (1966) adlı bilgisayar programının yankılandığı dönemlerden günümüze kadar güncelliğini korumaktadır. Arf'in, basit hesaplamaya dayalı problemleri çözebilen ve cevabını da kendine has diliyle fakat bizim anlayacağımı şekilde çıktılarında veren iki makine tasarımını hem gövdesi hem de işlem yapabilme kabiliyeti hantal olan "ENIAC" (1946) adlı bilgisayara benzetmesi, onun döneminin teknolojik gelişmelerinden haberdar olduğunu da kanıtlamaktadır.

Arf beynimizin iki temel çalışma prensibini makinelere uyarladığında, girdi ve çıktı arasındaki bağların benzerlerini imgeleyerek düşünen makineleri "analog"; bir problemin çözülme sürecinde ulaşılması gereken tüm sonuçları göz önüne alıp verilerle uyuşmayan sonuçları eleyerek düşünenleri de "dijital” makineler olarak kategorileştirmiştir. Fakat Arf'in bu tespitinde dijital makineler, mantıksal ve analitik işlemleri yapabilen analitik makinelere benzer göründüğünden, 0 ve 1 sembollerini işleyen Turing makinesine benzemektedir. Arf; bir makinenin ona verilen 
belli sayıda problemi çözebileceğini, bunun aksine yeni karşılaşth̆̆ problemleri çözemeyeceğini vurgulamakta ve onu yapay bir beyin olarak görmememiz gerektiğini belirtmektedir. Programlanma özelliği olan yapay beyin, yazılım adı verilen bir bilgi paketi ve onunla tepkimeye giren donanım aygıtından oluştuğundan girdilere cevap niteliğinde çıktılar üretir. Fakat insan beyni ve onun zihinsel süreçleri, makinenin aksine, yeni durumlara uyum sağlayabilme niteliğine sahiptir. Bu nedenle insan beyni ve makinenin işleyiş benzerliği tekrar gözden geçirilmelidir. Arf açısından insanlar bir problemi çözerken, öncelikle problemin sorusunu ön hafizasına alır ve tasnif bölgesini etkinleştirerek merkez hafizasından problemle ilgili bilgilerinin kopyalarını tekrar ön hafizasına yollar. Burada mantıki hesap ya da benzerlikle düşünerek, bilgiler çeşitli transformasyonlara uğrar ve sonuç ortaya çıkar. Arf'in bu tespiti, Newell ve Simon'un insan ve makinenin problem çözme benzerliklerini göstermeye çalıştıkları bellek modeli ile benzer görünmektedir. Çünkü Arf, ön hafiza demekle kısa süreli belleği, merkez hafiza demekle de uzun süreli belleği kasteder. Bunun yanı sıra makinenin verileri alış dili, girdiler olarak yorumlanır. Beynimiz söz konusu olduğunda da alış dilini kelimeler oluşturur. Burada dikkat edilmesi gereken husus, bizim, 29 harfin sıralanışını etki kabul ederek bunları hafizamızda işlememiz ve yeni problemlere çözümler üretebilmemizin dilimizin zenginliği ile ilgili olmayışıdır. 0 ve 1 işaretlerine dayalı algoritmaları kullanarak ve işleyerek de problem çözülmüş olur. İnsan için çok uzun harflerden oluşan bir kelime anlamsızlaşırken, Shannon'un matematiksel iletişim kuramı, makineler için 0 ve 1 işaretlerinin uzun uzadıya sıralanışları karmaşık bir hâle gelse de ya da bilgi içeriği az sayıda işaretle temsil edilse de makinenin gerekli veriyi alacağına dikkat çektiğinden; Arf'in, makinelerin, 0 ve 1 işaretlerinin azlığına dayanan girdileri alıp bilgiye dönüştüreceği kabulünü de onaylar görünmektedir.

Arf; elektronik beyin diyebileceğimiz makinelerde, 0 ve 1 işaretlerinin kullanıldığını ve onların çok basit esaslara göre yapıldıklarını ifade ederken, ön hafiza ve hafiza kısımlarının önermeler mantığına uygun şekilde dilsel verileri işlediği tespitinde bulunmaktadır. Arf'in kontrol cihazı diye adlandırdı̆̆ı kısım makinelerdeki işletim birimlerine karşılık gelen, ön hafiza ve hafiza girdi-çıktılarını; tümel evetleme, tikel evetleme, ise, o hâlde gibi girdiler olarak işlediğinde çıktılarını da mantık kurallarına uygun olarak verir. Bunun yanı sıra makinedeki elektrik devrelerinin açık ya da kapalı oluşlarına göre önermelerin hangi koşullarda doğru veya yanlış olduğu da bilinebilir. Arf'in yaptı̆̆ bu tespit, mantıki işlemlerin makinede nasıl vukuu bulduğuna ilişkin basit bir anlatım olarak karşımıza çıkmaktadır. Fakat makinelerin problem çözerken insana kıyasla, hâlâ, sınırlı kapasitelerinin olduğu inancı kabul görmektedir. Arf açısından da bir makine, sınırlı kapasitesinden dolayı, yeni karşılaştiğı 
problemlerin çözümüne karar veremeyecek, çözemeyeceği problemlerle karşılaşacak ya da çözüme dair yanlış yanıtlar verecektir. Turing; makinelere yöneltilecek bu eleştirinin farkında olarak Gödel'in "eksiklik teoremi"ni, tutarlı mantıksal bir sistem içinde çözülemeyecek problemlerin bulunması ve kanıtlanan kadar kanıtlanamayan önermelerin de sistemde bulunmasının doğal karşılanması gerekliliğini açığa çıkardığından, tıpkı insanlar gibi makinelerin de bazı problemleri çözemeyeceğini belirterek mantık önermelerinin doğru ve yanlışlığına karar verme probleminin doğal karşılanması gerekliliğini insan ve makine arasındaki farkı azaltmaya yönelik kullanmaktadır. Dolayısıyla Arf'in insan ve makine arasındaki farkı belirginleştiren tespiti, Turing tarafindan Gödel'in eksiklik teorimi aracılığıyla geçersizleştirilir.

Öte yandan Arf, insan ve makine arasındaki farkı belirginleştirmek amacıyla bir adım daha atarak insanın estetik bilince sahip bir süje oluşunu ön plana çıkarmaktadır; insan beyninin estetik yargı üretebilme ve bu yargılarına yönelik eyleyebilme özgürlüğü onun mahiyetidir. Estetik bilinç, mantıksal ve kural tabanlı işlemler öbeğiyle işlemez, bu nedenle, belirsizlik unsuru içinde işleyen ve atom altında gerçekleşen eylemlere benzer. Arf'in bu tespiti; “kuantum mekaniği teorisi”nin temel prensipleri olan, evrende gerçekleşen tüm olayların süreçler olarak anlaşılması gerekliliğinin yanı sıra onların tanecikli yapılar temelinde, belirsizlik ve ilişkisellik içinde gerçekleştiği inancına paraleldir. Ancak makineler, kuantum mekaniğinin ön gördüğü işleyiş prensiplerine göre yapılandırılabilirse estetik bilinç onlarda hâsıl olacaktır. Fakat bunun gerçekleşmesi ya mümkün değildir ya da çok uzun zamanlar alacaktır. Arf'in bu varsayımı, günümüzde popülerlik kazanan "kuantum bilgisayarı" üretme hayaline dayalı yeni algoritmalar yazma çalışmalarına öngörü olarak düşünüldüğünde, bu işin zorluğunu da bildirmektedir.

\section{Notlar}

1. Matematikçi ve bilim insanı vasıflarıyla tanınan Cahit Arf (11 Ekim 1910- 26 Aralık 1997), doktorasın 1938 yılında Göttingen'de Helmut Hasse'nin doktora danışmanlığında "Hasse-Arf Teoremi"ni ispatlayarak kazanmıştır. Bunun yanı sıra "Arf Halkaları" ve "Arf Kapanışları" adlı denklemleriyle matematik dünyasında yankı uyandırmıştır (Nesin, 2005, s. 104).

2. Arf, konuşmasının ilk bölümünde, yeni kurulan bir üniversitenin ilk ders yılına konuşmacı olarak davet edildiğinden dolayı "ideal” üniversite düşüncesine değinmeyi uygun bulmuştur ve Erzurum'da kurulmuş olan bu üniversiteyi ileride bir bilim yuvası olarak görmek istediğinden söz etmiştir. Bunun yanı sıra Arf, bilim arzusunun doyurulmasına yönelik "anlama”ya dayalı bir eğitimin sebat ile sürdü- 
rülmesiyle Batılı ilim insanlarının mucize diye aksettirilen buluşlarının hiç de öyle olmadığının farkına varılmasını ve bizim de sadece aklımıza güvenerek ilim ve tekniğe dayalı işler başarabileceğimizi vurgulamıştır (1959, 91-93).

3. İnsan söz konusu olduğunda kullanılan "etki" ve "tepki" ifadelerini makine söz konusu olduğunda "girdi" ve "çıkt" ifade ikilisi ile yer değiştirip kullanmak daha makul olacağından çalışmanın sonraki bölümlerinde bu değişiklik gözetilmiştir.

\section{Çıkar Çatışması Beyanı}

Makale yazarı herhangi bir çıkar çatışması olmadığını beyan etmiştir.

\section{Kaynakça}

Arf, C. (1959). Makine Düşünebilir mi ve Nasıl Düşünebilir? Atatürk Üniversitesi 19581959 Öğretim Yılı Halk Konferansları(1), 91-103.

Büyük Mühendisler 1 "Claude Shannon". (2017). TMMOB EMO Ankara Şubesi Haber Bülteni(3).

Churchland, P. M. (2018). Madde ve Bilinç. (B. Ersöz, Çev.) İstanbul: Alfa.

Descartes. (1984). Metot Üzerine Konuşma. (K. S. Sel, Çev.) İstanbul: Sosyal Yayınlar.

Gödelek, K. (2013). Zihin Felsefesi. Eskişehir: Anadolu Üniversitesi.

Heil, J. (2015). Zihin Felsefesi Çağdaş Bir Giriş. (S. Akbıyık, \& M. Bilgili, Çev.) İstanbul: Küre. Ifrah, G. (2000). Hesabın Destanı. (K. Dinçer, Çev.) Tübitak.

Kurzweil, R. (2020). İnsanlık 2.0. (M. Şengel, Çev.) İstanbul: Alfa.

Leibniz, G. (2011). Leibniz Monadoloji Metafizik Üzerine Konuşma. (A. Altınörs, Çev.) Ankara: Doğu Bat.

McCarthy, J., Minsky, M. L., Rochester, N., \& Shannon, C. L. (1955). Dartmouthe Summer Research Project on Artificial Intelligence. A Proposal.

Moor, J. (2006). The Dartmouth College Artifical Intelligence Conference: The Next Fifty Years. Al Magazine(27), 87-91.

Nesin, A. (2005, Kış). 'Anlamak' Tutkunu Bir Matematikçi Cahit Arf. Matematik Dünyası, 102-104.

Newell, A., \& Simon, A. H. (1972). Human Problem Solving. New Jersey: Prentice- Hall. Nilsson, N. J. (1995). Eye on the Prize. Al Magazine(16), 9-17.

Ömerustaoğlu, A. (2007). Bir İnsani Fenomen Olarak Estetik Bilinç. KKEFD(15), 18-26.

Penrose, R. (2016). Zihnin Gölgeleri. (B. Gönülşen, Çev.) İstanbul: Alfa Bilim.

Platon. (2011). Menon. Platon Diyaloglar (A. Cemgil, Çev., s. 149-188). içinde İstanbul: Remzi.

Raatikainen, P. (2021). Gödel's Incompleteness Theorems. The Stanford Encyclopedia of Philosophy (Spring 2021 Edition): https://plato.stanford.edu/entries/goedel-incompleteness/ adresinden alındı

Reyhani, N. (2020, Haziran). Eski soruyu bugün yeniden sormak Akıl nedir? Bilim ve Gelecek(194), 13-25. 
Rovellı, C. (2019). Gerçek Göründüğü Gibi Değildir. (T. Esmer, Çev.) İstanbul: Can.

Ryle, G. (2011). Zihin Kavramı. (S. Çelik, Çev.) İstanbul: Doruk.

Searle, J. R. (2016). Bilinç ve Dil. (M. Macit, \& C. Özpilavcı, Çev.) İstanbul: Litera.

Searle, J. R. (2020). Bilincin Gizemi. (I. Karagöz İçyüz, Çev.) İstanbul: Küre.

Shannon, C. E. (1948). A Mathematical Theory of Communication. The Bell System Technical Journal, 623-656.

Skinner, B. F. (1957). Verbal Behavior. Printed In The United States Of America.

Solso, R. L., Maclin, M. K., \& Maclin, O. H. (2010). Bilişsel Psikoloji. (A. Ayçiçeği-Dinn, Çev.) İstanbul: Kitapevi.

Tarlacı, S. (2009). Kuantum Beyin. www.KuantumBeyin.com.

Tunalı, i. (1983). Estetik Beğeni. İstanbul: Say.

Turing, A. M. (1936). On Computable Numbers with an Application to the Entscheidungsproblem. Proceedings of the London Mathematical Society(42), 230265.

Turing, A. M. (1950). Computing Machinery and Intelligence. Mind (49), 433-460.

Yılmaz, A. (2020). Yapay Zeka. İstanbul: İnkılap.

Zeman, A. (2006). Bilinç Kullanma Klavuzu. (G. Koca, Çev.) İstanbul: Metis. 


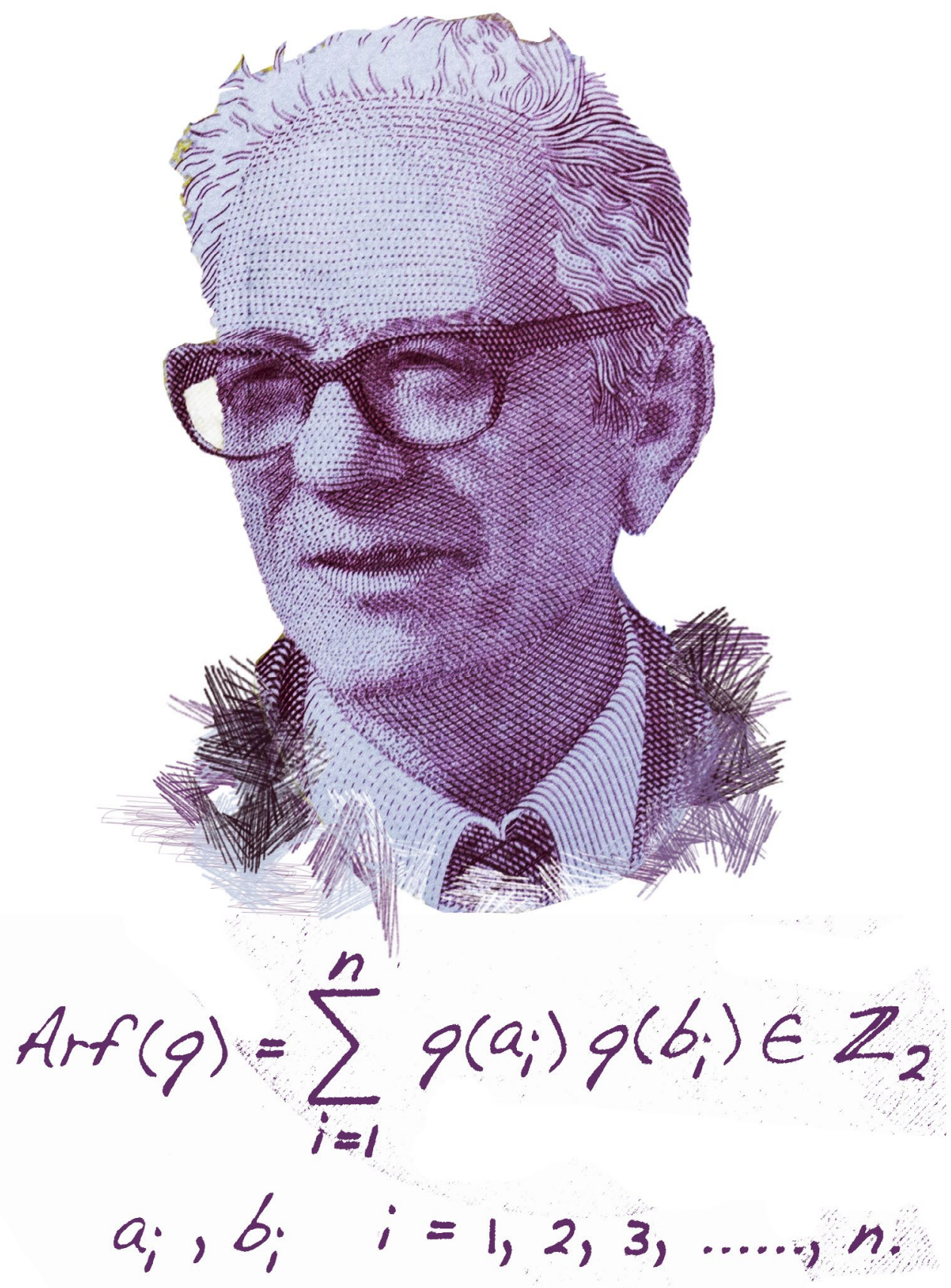

Anadolu Ajansı 